\title{
Deoxyribonucleic Acid Relatedness Among Erwiniae and Other Enterobacteriaceae: the Gall, Wilt, and Dry- Necrosis Organisms (Genus Erwinia Winslow et al., sensu stricto)
}

\author{
DON J. BRENNER, G. R. FANNING, AND A. G. STEIGERWALT \\ Division of Biochemistry, Walter Reed Army Institute of Research, Washington, D.C. 20012
}

\begin{abstract}
Species representing the genus Erwinia (sensu stricto, the gall-, wilt-, and dry-necrosis-producing phytopathogens) were examined for relatedness to each other, to pectobacteria, and to other members of the family Enterobacteriaceae. The technique employed to show relatedness was deoxyribonucleic acid (DNA) hybridization and hydroxyapatite chromatography. The results indicate that all erwiniae are significantly related to Pectobacterium and to other enterobacteria. DNA relatedness reveals six species of Erwinia: E. amylovora, E. nigrifluens, $E$. quercina, $E$. rubrifaciens, $E$. salicis, and $E$. tracheiphila. $E$. nigrifluens, $E$. rubrifaciens, and $E$. salicis show close intrageneric relatedness, whereas the other species exhibit as much relatedness to members of other genera as to the other Erwinia species. The data support the two-genus concept of Erwinia and Pectobacterium.
\end{abstract}

As presently constituted in Bergey's Manual (1), the genus Erwinia Winslow et al. contains an extremely diverse assortment of organisms, all of which are supposed phytopathogens. Organisms that cause wilts, galls, or dry necrosis, but not soft rot, comprise the genus Erwinia sensu stricto. It has been suggested that organisms causing soft-rot diseases be placed in the genus Pectobacterium Waldee (23). We have followed this suggestion in earlier publications (5; D. J. Brenner, A. G. Steigerwalt, G. R. Fanning, and A. Kelman, unpublished data) and shall continue to do so in this report.

Since the latest edition of Bergey's Manual, which was published in 1957, several investigators have studied taxonomic parameters in erwiniae. Although often disagreeing on specific taxonomic and nomenclatural designations, the investigators usually agree that the tribe Erwinieae contains four kinds of organisms. In addition to phytopathogenic erwiniae and pectobacteria, there are yellow-pigmented organisms which in many cases are of doubtful phy topathogenicity. These organisms are often isolated from animals and man. Ewing and Fife (12) placed them in Enterobacter as E. agglomerans. Finally, existing strains of Erwinia dissolvens and Erwinia nimipressuralis are thought of as either grossly atypical erwiniae or members of Klebsiella or Enterobacter. Unpublished studies from our laboratory indicate that one of our $E$. dissolvens strains belongs to Klebsiella. The other strains of $E$. dissolvens and $E$. nimipressuralis are most closely related to Enterobacter cloacae.

Two of our previous studies dealt with members of Pectobacterium (5; Brenner, Steigerwalt, Fanning, and Kelman, unpublished data). This report treats the phytopathogenic species of Erwinia sensu stricto, as typified by Erwinia amylovora. Interspecific deoxyribonucleic acid reassociation reactions were carried out to assess molecular relatedness among Erwinia species and between these organisms and other enterobacteria.

\section{MATERIALS AND METHODS}

Bacterial strains. The strains used in this study are listed in Table 1.

Methods. The general protocol for the experiments reported here is to choose a series of organisms as reference strains, label their deoxyribonucleic acid (DNA) with ${ }^{32} \mathrm{PO}_{4}$, shear and denature the labeled DNA, and allow it to reassociate with a 1500 -fold excess of similarly prepared, unlabeled DNAs from the homologous organism and other organisms of interest (4). The concentration of labeled DNA $(0.1 \mu \mathrm{g} / \mathrm{ml})$ is small enough to prevent significant reassociation of 
TABLE 1. Bacterial strains studied

\begin{tabular}{|c|c|}
\hline Organism & Source ${ }^{a}$ \\
\hline Citrobacter diversus 1066-70 & $\mathrm{CDC}$ \\
\hline C. freundii $460-61$ & CDC \\
\hline Edwardsiella tarda $1483-59$ & CDC \\
\hline E. tarda $3888-64$ & CDC \\
\hline Enterobacter aerogenes $1627-66$ & $\mathrm{CDC}$ \\
\hline $\begin{array}{l}\text { E. agglomerans (Erwinia herbicola) } \\
\text { EH } 103\end{array}$ & ICPB \\
\hline $\begin{array}{l}\text { E. agglomerans (E. herbicola) } \\
2553\end{array}$ & ICPB \\
\hline $\begin{array}{l}\text { E. agglomerans (E. herbicola) } \\
14589\end{array}$ & ATCC \\
\hline $\begin{array}{l}\text { E. agglomerans (E. lathyri) } \\
\text { EL } 102\end{array}$ & ICPB \\
\hline $\begin{array}{l}\text { E. agglomerans (E. uredovora) } \\
19321\end{array}$ & ATCC \\
\hline E. agglomerans $486-51$ & $\mathrm{CDC}$ \\
\hline E. agglomerans $1645-71$ & $\mathrm{CDC}$ \\
\hline E. cloacae $256-4$ & NIH \\
\hline E. cloacae 1347-71 & $\mathrm{CDC}$ \\
\hline E. hafniae $4360-67$ & $\mathrm{CDC}$ \\
\hline Erwinia amylovora EA 169 & ICPB \\
\hline E. amylovora EA 178 & ICPB \\
\hline E. amylovora 7400 & ATCC \\
\hline E. amylovora 7401 & ATCC \\
\hline E. amylovora 15357 & ATCC \\
\hline E. amylovora 15580 & ATCC \\
\hline E. amylovora 19382 & ATCC \\
\hline E. nigrifluens EN 101 & ICPB \\
\hline E. nigrifluens EN 104 & ICPB \\
\hline E. quercina $\mathrm{EQ} 101$ & ICPB \\
\hline E. quercina $\mathrm{EQ} 102$ & ICPB \\
\hline E. rubrifaciens ER 103 & ICPB \\
\hline E. rubrifaciens ER 105 & ICPB \\
\hline E. salicis ES 102 & ICPB \\
\hline E. salicis 15712 & ATCC \\
\hline E. tracheiphila 27004 & ATCC \\
\hline Escherichia coli $\mathrm{K}-12$ & U. of Washington \\
\hline Klebsiella pneumoniae 2 & CDC \\
\hline $\begin{array}{l}\text { Pectobacterium carnegieana } \\
\quad \text { EC } 186\end{array}$ & ICPB \\
\hline P. carotovorum 495 & ATCC \\
\hline P. chrysanthemi SR 32 & U. of Wisconsin \\
\hline $\begin{array}{l}\text { P. chrysanthemi pathovar } \\
\text { zeae SR } 80\end{array}$ & U. of Wisconsin \\
\hline P. cypripedii EC 155 & ICPB \\
\hline P. rhapontici ER 106 & ICPB \\
\hline Proteus mirabilis 1 & WRAIR \\
\hline Red Mouth Bacterium & $\mathrm{CDC}$ \\
\hline Salmonella cholerasuis 36 & CDC \\
\hline S. typhimurium LT2 & $\mathrm{NIH}^{1}$ \\
\hline Serratia marcescens SM6 & WRAIR \\
\hline
\end{tabular}

${ }^{a} \mathrm{CDC}$, Center for Disease Control, Atlanta, Ga., from W. H. Ewing and G. Hermann; ICPB, International Collection of Phytopathogenic Bacteria, Univ. of California, Davis, from M. P. Starr; ATCC, American Type Culture Collection, Rockville, Md; NIH, National Institutes of Health, Bethesda, Md., from V. J. Brenner; $\mathrm{NIH}^{1}$ from T. Theodore; WRAIR, Walter Reed Army Institute of Research. labeled DNA fragments with one another during the course of incubation. The concentration of unlabeled DNA is sufficiently high to insure complete reassociation of labeled DNA with unlabeled DNA ( 70 to $97 \%$ in practice). When the reaction is completed, reassociated (also termed hybridized, duplexed, or related) DNA is separated from unreacted DNA on hydroxyapatite (HA). At the phosphate concentration employed, double-stranded DNA binds to HA, but single-stranded DNA is eluted. The DNA bound to HA is eluted either by raising the phosphate concentration or by increasing the temperature until the DNA is denatured and elutes as single-stranded DNA (3). Two parameters of relatedness may be assessed. Percentage of relative relatedness is determined by normalizing the amount of DNA bound to HA in heterologous reactions to that bound in the homologous reaction where labeled and unlabeled DNA are from the same organism. Divergence in reassociated nucleotide sequences can be approximated by comparing the thermal stability of heterologous DNA duplexes with that of the homologous DNA duplex. Since each $1 \%$ of unpaired bases results in an approximate $1 \mathrm{C}$ decrease in thermal stability (17), the decrease in heterologous DNA duplex stability may be expressed as percentage of divergence. These methods have been discussed in detail previously (4).

The comparison of relative relatedness values obtained at an optimal and stringent reassociation criterion provides a third index of relatedness. The optimal temperature for reassociation is 25 to $30 \mathrm{C}$ below the temperature at which a given DNA is denatured, which in these experiments is $60 \mathrm{C}$. The 75 $\mathrm{C}$ temperature is the stringent incubation condition, at which only closely related sequences can reassociate. At $60 \mathrm{C}$, up to $20 \%$ unpaired bases may be present in DNA duplexes; at $75 \mathrm{C}$, less than $7 \%$ unpaired bases are tolerated (2).

The above-mentioned methods have been discussed in detail previously (3-5).

\section{RESULTS}

In Table 2 are shown the hybridization data from Erwinia amylovora EA 178 and $E$. quercina $\mathrm{EQ} 102$ reactions carried out at $60 \mathrm{C}$. The seven strains of $E$. amylovora are extremely closely related. Relatedness of $E$. amylovora to other erwiniae is only 13 to $23 \%$. A similar low level of relatedness is seen between E. amylovora and species of Pectobacterium, Enterobacter, Klebsiella, Serratia, Escherichia, Salmonella, Citrobacter, Edwardsiella, and Proteus. The two strains of $E$. quercina are highly interrelated $(91 \%)$. E. quercina is also not highly related to any other species of enterobacteria, its relatedness being 16 to $32 \%$ with other species of Erwinia, 20 to $33 \%$ with pectobacteria, and 19 to $25 \%$ with other enterobacteria (except Proteus mirabilis: 7\%).

A somewhat different pattern of relatedness 
TABLE 2. Relatedness of Erwinia amylovora EA 178 and Erwinia quercina EQ 102 to various enterobacteria

\begin{tabular}{|c|c|c|}
\hline \multirow[b]{2}{*}{ Source of unlabeled DNA } & \multicolumn{2}{|c|}{$\%$ relative binding at $60 \mathrm{C}$ of DNA from } \\
\hline & E. amylovora EA 178 & E. quercina $\mathrm{EQ} 102$ \\
\hline Erwinia amylovora EA 178 & 100 & 18 \\
\hline E. amylovora ATCC 15357 & 105 & 23 \\
\hline E. amylovora EA 169 & 104 & 26 \\
\hline E. amylovora ATCC 19382 & 101 & 21 \\
\hline E. amylovora ATCC 7400 & 100 & 22 \\
\hline E. amylovora ATCC 15580 & 93 & 20 \\
\hline E. amylovora ATCC 7401 & 85 & 16 \\
\hline E. quercina $\mathrm{EQ} 101$ & 13 & 100 \\
\hline E. quercina $\mathrm{EQ} 102$ & 14 & 91 \\
\hline E. rubrifaciens ER 103 & 15 & 27 \\
\hline E. rubrifaciens ER 105 & 15 & 27 \\
\hline E. salicis ES 102 & 21 & 31 \\
\hline E. salicis ATCC 15712 & 21 & 30 \\
\hline E. tracheiphila ATCC 27004 & 23 & 15 \\
\hline E. nigrifluens EN 101 & 17 & 32 \\
\hline E. nigrifluens EN 104 & 16 & 31 \\
\hline Pectobacterium carnegieana EC 186 & 14 & 26 \\
\hline P. carotovorum ATCC 495 & 16 & 27 \\
\hline P. chry santhemi pathovar zeae SR 80 & 16 & 33 \\
\hline P. cypripedii EC 155 & 22 & 20 \\
\hline Enterobacter agglomerans EL 102 & 23 & 21 \\
\hline E. agglomerans 2553 & 24 & 20 \\
\hline E. agglomerans $\mathrm{EH} 103$ & 25 & 23 \\
\hline Serratia marcescens SM6 & 25 & 25 \\
\hline Klebsiella pneumoniae 2 & 19 & 21 \\
\hline Enterobacter aerogenes 1627-66 & 19 & 22 \\
\hline Escherichia coli $\mathrm{K}-12$ & 17 & 23 \\
\hline Citrobacter freundii 460-61 & 17 & 19 \\
\hline Enterobacter hafniae $4360-67$ & 15 & 19 \\
\hline Salmonella typhimurium LT2 & 14 & 21 \\
\hline Edwardsiella tarda $3888-64$ & 17 & \\
\hline Proteus mirabilis 1 & 7 & 7 \\
\hline
\end{tabular}

is seen with E. salicis ATCC 15712 (Table 3). E. salicis ES 102 and ATCC 15712 are indistinguishable. $E$. salicis is most closely related to $E$. rubrifaciens. These organisms exhibit $55 \%$ average relatedness at $60 \mathrm{C}$, and one-half of the related sequences remain stable at $75 \mathrm{C}$. Ten percent of the unpaired bases (divergence) are present in the duplexes formed at $60 \mathrm{C}$. $E$. nigrifluens is somewhat less related to $E$. salicis (45\% binding, $12 \%$ divergence at $60 \mathrm{C} ; 18 \%$ binding at $75 \mathrm{C}$ ). The relatedness of $E$. salicis to other Erwinia species is 20 to $33 \%$ at $60 \mathrm{C}$, falling to about $5 \%$ at $75 \mathrm{C}$. These duplexes exhibit 15 to $17 \%$ divergence.

The relatedness of $E$. salicis to pectobacteria is 21 to $42 \%$. The highest pectobacterium reaction is with Pectobacterium carnegieana. $P$. rhapontici ER 106 is $95 \%$ related to $E$. salicis at $60 \mathrm{C}$ and $100 \%$ related at $75 \mathrm{C}$. These duplexes show no evidence of divergence. We are convinced that this culture of strain ER 106 belongs, in fact, to $E$. salicis rather than to $P$. rhapontici. The relatedness of $E$. salicis to other enterobacteria is 16 to $34 \%$.

Relatedness patterns similar to that of $E$. salicis were obtained using reference DNA from $\bar{E}$. nigrifluens EN 104 and $E$. rubrifaciens ER 105 (Table 4). The two $E$. nigrifluens strains used in this study are indistinguishable, as are the two $E$. rubrifaciens strains. E. rubrifaciens and $E$. salicis are again shown to be the most closely related species of Erwinia at both the 60 $\mathrm{C}$ and $75 \mathrm{C}$ criteria. The relatedness of Erwinia species to ER 105 and EN 104 is 19 to $54 \%$. Pectobacteria exhibit 20 to $34 \%$ relatedness to ER 105 and EN 104, and the relatedness of other enterobacteria (excluding $P$. mirabilis) to ER 105 and EN 104 is 16 to $25 \%$.

No strain of Enterobacter agglomerans studied was highly related to Erwinia species (Tables 2-4). These strains included organisms previously designated Erwinia herbicola, $E$. lathyri, or $E$. uredovora (Table 1). Studies in which DNA from several other Enterobacter 
TABLE 3. Relatedness of Erwinia salicis ATCC 15712 to enterobacteria

\begin{tabular}{|c|c|c|c|}
\hline \multirow[b]{2}{*}{ Source of unlabeled DNA } & \multicolumn{2}{|c|}{$60 \mathrm{C}$} & \multirow{2}{*}{$\begin{array}{c}\text { \% relative } \\
\text { binding } \\
\text { at } 75 \mathrm{C}\end{array}$} \\
\hline & $\%$ relative binding & $\%$ divergence $a$ & \\
\hline Erwinia salicis ATCC 15712 & 100 & & 100 \\
\hline E. salicis ES 102 & 98 & 0.0 & 100 \\
\hline E. rubrifaciens ER 105 & 60 & 11.7 & 34 \\
\hline E. rubrifaciens ER 103 & 52 & 9.2 & 28 \\
\hline E. nigrifluens EN 104 & 47 & 13.1 & 19 \\
\hline E. nigrifluens EN 101 & 45 & 11.3 & 17 \\
\hline E. quercina $\mathrm{EQ} 102$ & 33 & 15.2 & 7 \\
\hline E. amylovora EA 178 & 22 & 15.9 & 6 \\
\hline E. tracheiphila ATCC 27004 & 20 & 17.0 & 4 \\
\hline Pectobacterium carnegieana EC 186 & 42 & 12.7 & 9 \\
\hline P. chrysanthemi SR 32 & 32 & 15.7 & 6 \\
\hline P. cypripedii EC 155 & 21 & 16.3 & 5 \\
\hline P. rhapontici ER 106 & 95 & 0.0 & 100 \\
\hline Enterobacter agglomerans $1645-71$ & 33 & & \\
\hline E. agglomerans $486-51$ & 31 & & \\
\hline E. agglomerans ATCC 19321 & 31 & & \\
\hline Citrobacter diversus $1066-70$ & 25 & & \\
\hline C. freundii $460-61$ & 27 & & \\
\hline Salmonella cholerasuis 36 & 27 & 15.1 & 5 \\
\hline Escherichia coli $\mathrm{K}-12$ & 22 & 16.2 & 7 \\
\hline Edwardsiella tarda $1483-59$ & 21 & 15.8 & 4 \\
\hline Enterobacter cloacae $256-4$ & 20 & & \\
\hline E. cloacae $1347-71$ & 20 & & \\
\hline Serratia marcescens SM6 & 19 & & \\
\hline Red Mouth Bacterium & 17 & & \\
\hline Enterobacter aerogenes $1627-66$ & 16 & & \\
\hline E. hafniae 4360-67 & 16 & & \\
\hline
\end{tabular}

${ }^{a}$ Percent divergence is calculated on the assumption that each $1 \mathrm{C}$ decrease in thermal stability of a heterologous DNA duplex compared to that of the homologous DNA duplex is caused by $1 \%$ unpaired based within the duplex (17).

agglomerans was tested (data not shown) confirm the lack of a high level of relatedness between E. agglomerans and Erwinia. Dye (8) and Ewing and Fife (12) consider Erwinia milletiae and $E$. cassavae to be synonyms of $E$. herbicola (Enterobacter agglomerans). It must be noted, however, that our preliminary studies indicate the existence of several widely different hybridization groups in Enterobacter agglomerans,

These data may be summarized as follows. (i) Neither Erwinia amylovora nor E. quercina exhibit significantly more than the core level of relatedness to any other species of Enterobacteriaceae. (ii) Erwinia rubrifaciens, E. salicis, and $E$. nigrifluens are about $50 \%$ interrelated. The range of relatedness of these organisms to other erwiniae overlaps with their relatedness range to pectobacteria. (iii) Erwinia tracheiphila shows its highest relatedness $(38 \%)$ to $E$. rubrifaciens. (iv) All six species of Erwinia studied here fall into clearly different hybridization groups.

\section{DISCUSSION}

Gardner and Kado (13) obtained DNA hybridization data from several Erwinia species, particularly Erwinia rubrifaciens and E. amylovora. They used the DNA filter technique in the presence of formamide and assayed both direct DNA binding and DNA competition at several temperatures between 18 and $36 \mathrm{C}$ below the thermal elution midpoint of their labeled DNA. Despite the use of a different method, largely different strains, and different temperatures of incubation, their data and those reported here are in good general agreement.

Results from the more recent studies attest to the existence of four groups of organisms within the genus Erwinia as presently described in Bergey's Manual (1). There is general agreement that one of these groups, the so-called "atypical erwiniae," is composed of organisms that belong, in fact, to Enterobacter or to Klebsiella pneumoniae $(9,10)$. Many, but 
TABLE 4. Relatedness of Erwinia nigrifluens EN 104 and Erwinia rubrifaciens ER 105 to various enterobacteria

\begin{tabular}{|c|c|c|c|}
\hline \multirow[b]{3}{*}{ Source of unlabeled DNA } & \multicolumn{3}{|c|}{$\%$ relative binding } \\
\hline & \multirow{2}{*}{$\frac{E . \text { nigrifluens EN } 104^{a}}{60 \mathrm{C}}$} & \multicolumn{2}{|c|}{ E. rubrifaciens ER $105^{a}$} \\
\hline & & $60 \mathrm{C}$ & $75 \mathrm{C}$ \\
\hline Erwinia nigrifluens EN 104 & 100 & 42 & 21 \\
\hline E. nigrifluens EN 101 & 103 & 46 & 23 \\
\hline E. rubrifaciens ER 105 & 44 & 100 & 100 \\
\hline E. rubrifaciens ER 103 & 45 & 101 & 101 \\
\hline$E$. salicis ATCC 15712 & 47 & 53 & 31 \\
\hline E. salicis ES 102 & 45 & 54 & 30 \\
\hline E. quercina $\mathrm{EQ} 102$ & 30 & 26 & 8 \\
\hline E. quercina $\mathrm{EQ} 101$ & 29 & 25 & 9 \\
\hline E. tracheiphila ATCC 27004 & & 38 & 7 \\
\hline E. amylovora ATCC 19382 & 24 & 23 & \\
\hline E. amylovora ATCC 15580 & 23 & 21 & \\
\hline E. amylovora ATCC 15357 & 23 & 23 & \\
\hline E. amylovora EA 178 & 22 & 22 & 7 \\
\hline E. amylovora ATCC 7400 & 22 & 20 & 7 \\
\hline E. amylovora ATCC 7401 & 19 & 20 & 7 \\
\hline Pectobacterium carnegieana EC 186 & 34 & 32 & 9 \\
\hline P. carotovorum ATCC 495 & 32 & 34 & 11 \\
\hline P. chrysanthemi pathovar zeae SR 80 & 28 & 28 & 8 \\
\hline P. cypripedii EC 155 & 21 & 20 & 7 \\
\hline Enterobacter agglomerans $\mathrm{EH} 103$ & 23 & 22 & 7 \\
\hline E. agglomerans EL 102 & 21 & 20 & 7 \\
\hline E. aerogenes $1627-66$ & 25 & 20 & 8 \\
\hline Klebsiella pneumoniae 2 & 25 & 19 & \\
\hline Serratia marcescens SM6 & 25 & 23 & 8 \\
\hline Salmonella typhimurium LT2 & 23 & 20 & 9 \\
\hline Escherichia coli $\mathrm{K}-12$ & 21 & 20 & 8 \\
\hline Citrobacter freundii $460-61$ & 19 & 17 & 8 \\
\hline Enterobacter hafniae $4360-67$ & 18 & 19 & 6 \\
\hline Edwardsiella tarda $3888-64$ & & 16 & \\
\hline Proteus mirabilis 1 & 8 & 6 & \\
\hline
\end{tabular}

${ }^{a}$ Source of unlabeled DNA.

not all, strains of $P$. carnegieana do in fact belong to $K$. pneumoniae (5). Available cultures labeled Erwinia dissolvens or Erwinia nimipressuralis are either strains of Enterobacter cloacae or are quite closely related to $E$. cloacae $(5,9,10)$. Further study is needed before these organisms can be placed in the appropriate species.

The second group contains the species $E r$ winia cassavae and $E$. milletiae (and possibly $E$. vitivora) as well as strains designated $E$. herbicola, E. lathyri, E. uredovora, E. maydis, Xanthomonas trifolii, $E$. ananas, etc. $(9,10)$. About two-thirds of these organisms produce a yellow pigment (10). Their validity as phytopathogens is, in many cases, questionable. These organisms are being isolated from human infection with increasing frequency $(9,22)$, a fact "which has stimulated a good deal of interest in them on the part of medical bacteriologists. Dye has studied these organisms from a taxonomic point of view (8); von Graevenitz (22) and Ewing and Fife (12) have studied clinical isolates. These organisms are usually treated as a single species. Ewing and Fife (12) proposed the name Enterobacter agglomerans for these organisms and described seven anaerogenic and four aerogenic biogroups. DNA-relatedness studies in progress indicate that these organisms are significantly, although distantly (usually $35 \%$ or less), related to Erwinia, Pectobacterium, and to most other Enterobacteriaeceae (Brenner, unpublished results). These DNA-relatedness studies indicate the existence of at least four markedly different hybridization groups among these organisms. A more detailed discussion before more data are available is both academic at this time and beyond the scope of this paper.

A great many taxonomic schemes have been proposed for the remaining two groups in Erwiniae: the "true" erwiniae, including $E$. 
amylovora, the type species of Erwinia, and the pectolytic erwiniae, including Pectobacterium carotovorum, the type species of Pectobacterium. Most of these proposals are of four types. (i) Remove the "true" erwiniae from Enterobacteriaceae (10, 23). (ii) Retain the genus Erwinia as presently constituted in Bergey's Manual. (iii) Split the genus into two genera or two groups, one containing the pectolytic and related organisms and the other containing "true" erwiniae $(5,6,7,23)$. (iv) Distribute these organisms to other genera of Enterobacteriaceae based on biochemical similarity and without regard for phytopathogenicity $(16,19)$.

There are compelling reasons to retain both the "true" and the pectolytic erwiniae in Enterobacteriaceae. These include biochemical and genetic evidence (see reference 20), as well as DNA-hybridization data obtained previously $(5,13)$ and in this study. The data relating to the question of whether these organisms should be retained in the genus Erwinia, split into Erwinia and Pectobacterium, or largely distributed throughout other genera of Enterobacteriaceae are excellently treated in the review by Starr and Chatterjee (20). We have supported the two-genus concept because of the different metabolic patterns exhibited by $\mathrm{Er}$ winia sensu stricto and Pectobacterium, differences in type of disease production, and generally higher intragroup DNA relatedness. It is true that the guanine + cytosine $(G+C)$ composition in the DNA of these organisms does not correlate with the two-genus concept, as each genus contains organisms with $51 \%$ to about $57 \% \mathrm{G}+\mathrm{C}(21$; and Table 5). The single-genus concept does not alleviate the heterogeneous distribution of $\mathrm{G}+\mathrm{C}$ and does not take into account the biochemical and pathological differences between these organisms.

There are also many schemes for speciating erwiniae. Many of the earlier schemes, unfortunately, were based on the host from which the bacterium was isolated without information about host range of the newly isolated species or previously isolated species. This practice led to a variety of nomenclatural synonyms for the same species. Graham (15) and Dye (6-8) have carried out extensive studies to purge these synonyms from the literature. Objections to classification based on site of isolation have been firmly stated by both plant and medical bacteriologists $(7,11-14)$.

Some of the more recent proposals for speciation of Erwiniae are shown in Table 5 . The present Bergey's Manual (we are unaware of the makeup of Erwinia in the edition of Bergey's Manual that is in preparation) contains six species of Erwinia sensu stricto (1). Three of these, E. cassavae, E. milletiae, and $E$. vitivora, are from the $E$. herbicola, or Enterobacter agglomerans, group $(8,12)$. Three additional species, $E$. nigrifluens, $E$. quercina, and $E$. rubrifaciens, are not included in the current

TABLE 5. Comparison of some taxonomic groupings for Erwinia species

\begin{tabular}{|c|c|c|c|c|c|}
\hline Species & $\% \mathrm{G}+\mathrm{C}^{a}$ & $\begin{array}{c}\text { Bergey's } \\
\text { Manual (1) }\end{array}$ & $\begin{array}{l}\text { Martinec and } \\
\text { Kocur (18) }\end{array}$ & Dye (6) & Present study \\
\hline Erwinia & $53.6-54.9$ & E. amylovora & E. amylovora & E. amylovora & Erwinia \\
\hline E. cassavae & 55.1 & E. cassavae & $\begin{array}{l}\text { E. amylovora subsp. } \\
\text { salicis }\end{array}$ & $\begin{array}{l}\text { E. herbicola subsp. } \\
\text { herbicola }\end{array}$ & $\begin{array}{l}\text { Enterobacter } \\
\text { agglomerans }\end{array}$ \\
\hline E. milletiae & $54.1-55.1$ & E. milletiae & E. amylovora & $\begin{array}{l}\text { E. herbicola subsp. } \\
\text { herbicola }\end{array}$ & $\begin{array}{l}\text { Enterobacter } \\
\text { agglomerans }\end{array}$ \\
\hline E. nigrifluens & $56.1-56.7$ & & & $\begin{array}{l}\text { E. amylovora subsp. } \\
\text { nigrifluens }\end{array}$ & $\begin{array}{l}\text { Erwinia } \\
\text { nigrifluens }\end{array}$ \\
\hline E. quercina & $54.6-55.1$ & & & $\begin{array}{l}\text { E. amylovora subsp. } \\
\text { quercina }\end{array}$ & E. quercina \\
\hline E. rubrifaciens & $51.3-52.6$ & & & $\begin{array}{l}\text { E. amylovora subsp. } \\
\text { rubrifaciens }\end{array}$ & E. rubrifaciens \\
\hline E. salicis & $51.3-51.5$ & E. salicis & $\begin{array}{l}\text { E. amylovora subsp. } \\
\text { salicis }\end{array}$ & $\begin{array}{l}\text { E. amylovora subsp. } \\
\text { salicis }\end{array}$ & E. salicis \\
\hline E. tracheiphila & $50.0-52.0$ & E. tracheiphila & E. amylovora & $\begin{array}{l}\text { E. amylovora subsp. } \\
\text { tracheiphila }\end{array}$ & E. tracheiphila \\
\hline E. vitivora & & E. vitivora & E. amylovora & $\begin{array}{l}\text { Species incertae } \\
\text { sedis }\end{array}$ & $?$ \\
\hline
\end{tabular}

${ }^{a}$ All determinations of $\mathrm{G}+\mathrm{C}$ are from Starr and Mandel (21). In addition, determinations of Gardner and Kado (13) are used for E. amylovora, E. nigrifluens, and $E$. rubrifaciens. 
Bergey's Manual scheme. Martinec and Kocur (18) recognize only one species, E. amylovora, and one variety (subspecies), E. amylovora subsp. salicis. Dye also recognizes $E$. amylovora as the sole species but specifies five subspecies with the subspecific epithets nigrifluens, quercina, rubrifaciens, salicis, and tracheiphila (6).

Gardner and Kado (13) demonstrated that $E$. amylovora, E. rubrifaciens, and $E$. nigrifluens are separate species by virtue of their own DNA relatedness. Our data confirm and extend their findings, indicating that $E$. amylovora, $E$. quercina, $E$. rubrifaciens, $E$. nigrifluens, $E$. salicis, and $E$. tracheiphila are all distinct species. Of these, E. salicis, E. nigrifluens, and $E$. rubrifaciens are most closely related. The remaining species seem to share about the same level of core relatedness with Erwinia species, pectobacteria, and members of other genera of Enterobacteriaceae.

Although the genera Pectobacterium and Erwinia both contain some organisms of differeing $\mathrm{G}+\mathrm{C}$ content, and some organisms that do not exhibit high levels of intragenus relatedness, they are not unique among Enterobacteriaceae in these respects. The genus Enterobacter and the genus Proteus contain species that exhibit $20 \%$ or less relatedness at the genus level (Brenner, unpublished observations). Proteus species differ in $\mathrm{G}+\mathrm{C}$. content by as much as $13 \%$.

We believe that the most logical present course of action is to retain $E$. tracheiphila, $E$. quercina, E. amylovora, E. salicis, E. rubrifaciens, and $E$. nigrifluens in the genus Erwinia on the basis of their similar biochemistry and pattern of disease production. The alternative would be four genera: one for $E$. tracheiphila, one for $E$. quercina, one for E. amylovora, and one for $E$. salicis, $E$. rubrifaciens, and $E$. nigrifluens. Such a scheme has no merit because it splits organisms without any purpose.

The strain received as Pectobacterium rhapontici ER 106 is indistinguishable from $E$. salicis (Table 3 ). This strain was included in our previous study (5) as the only representative of $P$. rhapontici. Therefore the conclusion that $P$. rhapontici is a valid species of Pectobacterium must be withheld until valid strains of $P$. rhapontici are examined.

\section{REPRINT REQUESTS}

Address reprint requests to: Dr. Don J. Brenner, Division of Biochemistry, Walter Reed Army Institute of Research, Washington, D. C. 20012.

\section{LITERATURE CITED}

1. Breed, R. S., E. G. D. Murray, and N. R. Smith. 1957. Bergey's manual of determinative bacteriology, 7 th ed. The Williams and Wilkins Co., Baltimore.

2. Brenner, D. J., G. R. Fanning, K. E. Johnson, R. V. Citarella, and S. Falkow. 1969. Polynucleotide sequence relationships among members of the Enterobacteriaceae. J. Bacteriol. 98:637-650.

3. Brenner, D. J., G. R. Fanning, A. Rake, and K. E. Johnson. 1969. A batch procedure for thermal elution of DNA from hydroxyapatite. Anal. Biochem. 28:447-460.

4. Brenner, D. J., G. R. Fanning, F. J. Skerman, and S. Falkow. 1972. Polynucleotide sequence divergence among strains of Escherichia coli and closely related organisms. J. Bacteriol. 109: 953-965.

5. Brenner, D. J., A. G. Steigerwalt, G. V. Miklos, and G. R. Fanning. 1973. Deoxyribonucleic acid relatedness among erwiniae and other Enterobacteriaceae: the soft-rot organisms (genus Pectobacterium Waldee). Int. J. Syst. Bacteriol. 23: 205-216.

6. Dye, D. 1968. A taxonomic study of the genus Erwinia. I. The "Amylovora" group. N. Z. J. Sci. 11:590-607.

7. Dye, D. 1969. A taxonomic study of the genus Erwinia. II. The "Carotovora" group. N. Z. J. Sci. 12:81-97.

8. Dye, D. 1969. A taxonomic study of the genus Erwinia. III. The "Herbicola" group. N. Z. J. Sci. 12:223-236.

9. Dye, D. 1969. A taxonomic study of the genus Erwinia. IV. "Atypical" erwiniae. N. Z. J. Sci. 12:833-838.

10. Edwards, P. R., and W. H. Ewing. 1972. Identification of Enterobacteriaceae, 3rd ed. Burgess Publishing Co., Minneapolis.

11. Eichoff, T. C., B. W. Steinhauer, and M. Findland. 1966. The Klebsiella-Enterobacter-Serratia division: biochemical and serological characteristics and susceptibility to antibiotics. Ann. Intern. Med. 65:1 163-1179.

12. Ewing, W. H., and M. A. Fife. 1972. Enterobacter agglomerans (Beijerinck) comb. nov. (the Herbicola-Lathyri bacteria). Int. J. Syst. Bacteriol. 22:4-11.

13. Gardner, J. M., and C. I. Kado. 1972. Comparative base sequence homologies of the deoxyribonucleic acids of Erwinia species and other enterobacteria. Int. J. Syst. Bacteriol. 22:201-209.

14. Graber, C. D. 1970. The Enterobacteriaceae, p. 30-47. In C. D. Graber (ed.), Rapid diagnostic methods in medical microbiology. The Williams and Wilkins Co., Baltimore.

15. Graham, D. C. 1964. Taxonomy of the soft-rot coliform bacteria. Annu. Rev. Phytopathol. 2: $13-43$.

16. Komagata, K. 1970. Taxonomy of microorganisms (Proc. 10th Symp. Inst. Appl. Microbiol., Tokyo, 1968), p. 97-111. Univ. of Tokyo Press, Tokyo. 
17. Laird, C. D., B. L. McConaughy, and B. J. McCarthy. 1969. On the rate of fixation of nucleotide substitutions in evolution. Nature (London) 224:149-154.

18. Martinec, T., and M. Kocur. 1964. A taxonomic study of Erwinia amylovora (Burrill 1882) Winslow et al. 1920. Int. Bull. Bacteriol. Nomen. Tax. 14:5-14.

19. Moustardier, G., J. Brisou, J. Saout, and J. P. Ehrhardt. 1961. Les Erwinia-discussion taxinomique-interet medical. Bull. Ass. Diplomes. Microbiol. Fac. Pharm. Nancy 82:3-12.

20. Starr, M. P., and A. K. Chatterjee. 1972. The genus Erwinia: enterobacteria pathogenic to plants and animals. Annu. Rev. Microbiol. 26: 389-426.

21. Starr, M. P., and M. Mandel. 1969. DNA base composition and taxonomy of phytopathogenic and other enterobacteria. J. Gen. Microbiol. 56:113-123.

22. von Graevenitz, A. 1970. Erwinia species isolates. Ann. N.Y. Acad. Sci. 174:436-443.

23. Waldee, E. L. 1945. Comparative studies of some peritrichous phytopathogenic bacteria. Iowa State J. Sci. 19:435-484. 